\title{
Antixenosis Studies in Different Genotypes of Bitter Gourd Fruits against the Infestation of Melon Fruit Fly
}

\author{
Paras Nath $^{1}$, A. K. Panday ${ }^{2}$, Akhilesh Kumar ${ }^{2} \&$ Hemalatha Palanivel $^{1}$ \\ ${ }^{1}$ College of Agriculture, Fisheries and Forestry, Fiji National University, Koronivia, Fiji \\ ${ }^{2}$ Department of Entomology and Agricultural Zoology, Institute of Agricultural Sciences, Banaras Hindu \\ University, Varanasi, India \\ Correspondence: Hemalatha Palanivel, College of Agriculture, Fisheries and Forestry, Fiji National University, \\ Koronivia, Fiji. E-mail: hemalatha.palanivel@fnu.ac.fj
}

Received: October 14, 2016

Accepted: December 3, 2016

Online Published: January 15, 2017

doi:10.5539/jas.v9n2p226

URL: http://dx.doi.org/10.5539/jas.v9n2p226

\begin{abstract}
In crop plants, three principle mechanism viz., non-preference (antixenosis), antibiosis and tolerance are responsible for imparting resistance to insects. Non preference denotes a group of plants character and insect response that keep away the insect from using a particular plant or variety for oviposit ion, food, shelter, or combination of both. Keeping in this view, seventy four promising genotypes of bitter gourd were screened against fruit fly infestation to identify the antixenosis traits involved in host plant selection by the melon fruit fly. On the basis of percent fruit infestation and the average number of larvae per damage fruit, the genotypes were categorized in to different groups i.e. (Highly resistant, resistant, moderately resistant, susceptible, and highly susceptible). The fruit infestation during the 2006 and 2007 summer season (Average of two years) ranged from $13.23 \%$ to $83.75 \%$. Larval density per fruit ranged from 2.59 to 8.13 larvae per fruit. The larval density increased with the increase in percent fruit infestation and showed significant positive correlation $(r=0.98)$. The depth of ribs in resistant genotypes was higher as compared to susceptible genotypes. The number of seed was recorded maximum in the genotype VRBT-96 (31.8) and minimum was recorded in the genotype IC 68314(14.8). The fruit toughness had significant negative effect on fruit infestation $(r=-0.52)$ and larval density $(r=-0.57)$ of fruit fly. There was a strong correlation between number of ribs and fruit toughness, and these traits can be used as markers to select bitter gourd genotype resistant to melon fruit fly.
\end{abstract}

Keywords: genotypes, bitter gourd fruits, infestation, melon fruit fly

\section{Introduction}

The vegetables form an essential component of the human diet especially in the case of India and some Southeast Asian countries where sizable population basically consists of vegetarians. In the vegetable kingdom, cucurbitaceous crops occupy the major share in terms of kind of total crops grown, area covered, crops produced and consumed worldwide (Nath, 1965, 2008). In terms of nutritive value, bitter gourd (Momordica charentia L.) ranks first among cucurbits, being rich in iron, phosphorus and ascorbic acid (Awasthi \& Jaiswal, 1986). It is a popular vegetable cultivated all over the world especially in India, Pakistan, Srilanka and China (Panday et al., 2008).

In India, it is one the most important and round the year cultivated popular vegetable crops grown for its immature fruits which are consumed as stuffed-fried and in many other ways. It has immense medicinal properties due to the presence of beneficial phytochemicals which are known to have antibiotic, antimutagenic, antioxidant, antiviral, antidiabetic and immune enhancing properties (Grover \& Yadav, 2004). A compound known as charantin, present in the bittergourd is used in the treatment of diabetes in reducing blood sugar level (Lotlikar et al., 1966). Bitter gourd has good export potential and its share in export of green vegetable is to the extent of 20 per cent (Anonymous, 1992). Insect pests are a major constraint for increasing the production and productivity of this crop. Among them the fruit fly is one of the most destructive insect-pest (Panday et al., 2008). The melon fruit fly has been observed on 81 host plants but bitter gourd is one of the most preferred hosts and has been a major limiting factor in attaining good quality fruits and high yield (Panday et al., 2009; Lall \& Singh, 1969). Depending on the environmental conditions and susceptibility of the crop species, the extent of losses varies between 30 to 100\% (Dhillon et al., 2005a, 2005b, 2005c; Panday et al., 2009). 
The melon fruit fly is active throughout the year except for a short period from December to mid February (due to excessive cold). It prefers young, green and tender fruits as compared to bigger ones with hard rind for egg laying (Narayan, 1953). When eggs are hatched into maggots, they tunnel deep into fruit pulp and the entire fruits get spoiled.

There is no satisfactory chemical control of melon fruit fly, however, some pesticides such as malathion, dichlorovos, phosphamidon and endosulfan partially control its attack (Agarwal et al., 1987). The control measures adopted rely mainly on contact poison or baits (Gupta \& Verma, 1979; Lee, 1988). Contact poisons may have serious deleterious effect on health as fruits in India and other developing countries are consumed raw, often unwashed. The fruits of bitter gourd of which the melon fruit fly is a serious pest, are picked up at short interval for marketing and self consumption. Therefore, it is difficult to rely on insecticides as a means of controlling this pest (Panday et al., 2008). Hence development of resistant varieties is the most effective and cheapest method of controlling this pest. To identify the source of resistance, screening of bitter gourd germplasms against this pest is a pre-requisite to achieve this objective. The identification of morphological factors governing resistance is helpful in the development of rapid screening technique. The mechanism of resistance may be antixenosis, antibiosis and tolerance. The bitter gourd varieties having such inhibitory mechanism of resistance to melon fruit fly can be used in transferring the resistance in to the commercially acceptable varieties. Even partially resistant cultivars may also provide adequate control even with minimum usage of insecticides. It will help to prolong the useful commercial life of existing insecticides by discouraging the development of insecticides resistance strains of the insect. More recent research has found, for instance, that higher concentrations of glucosinolates and greater densities of trichomes in Arabidopsis thaliana reduced herbivory by two flea beetle species (Mauricio, 1998). These traits can also evolve as adaptive defences since there exists heritable variation for glucosinolate and trichome levels, and herbivores selected for an increase in these levels (Mauricio \& Rausher, 1997). We lack an understanding of the traits that are most strongly associated with resistance against this pest, and the relative importance of different types of traits involved in defense (Stamp, 2003). Keeping in view the above facts, the present work entitled "Antixenosis studies in different genotypes of bitter gourd against the infestation of melon fruit fly" was under taken.

\section{Materials and Methods}

Morphological resistance factors interfere physically with mechanisms of feeding and oviposition. Size and shape of bitter gourd fruits may affect the egg laying and developmental behaviour of fruit fly (Boller \& Prokopy, 1976). Such morphological factors which may provide resistance to melon fruit fly were investigated so that it could be possible to develop rapid screening techniques based on that factors. The experiments were conducted in the summer seasons of the year 2009 and 2010, to screen different genotypes of bitter gourd against the infestation of fruit fly. The fruit infestation was calculated based on the fly ovipuncture is visible. Sometimes it is difficult to view the ovipuncture, then the fruit rearing was done for a week to check the presence of larvae in the harvested fruit. All the damaged fruits were cut opened and count the number of larvae per fruit and averaged. The observations on fruit damage were recorded at weekly intervals from one week of fruit initiation stage till harvest the crop. All the genotypes were grouped in to different categories on the basis of percent fruit damage and number of larvae per fruit. Plant herbivore interactions are influenced by several morphological and biochemical plant traits, environmental conditions and physiological status of the tests insects (De- Ponti, 1977).

In the present study, morphological factors such as fruit length, fruit diameter, fruit flesh thickness, fruit skin thickness, ridge depth, number of ridge $\left(\mathrm{cm}^{-2}\right)$ area, number of seeds fruit ${ }^{-1}$, and fruit toughness, of different genotypes of bitter gourd were studied with a view to understand their contribution in imparting resistance or susceptibilities nature of bitter gourd plant. The fresh fruits were harvested from the experimental plots. Out of the harvested fruits of various germplasms, five fresh, healthy and average size fruits were selected to record the morphological characters. The observations on fruit diameter, were measured with the help of Verniercaliper. Depth of ribs were measured by cut the fruits longitudinally and depth of ribs was measured on two opposite sides and was averaged. All the fruits used for observation on depth of ribs were also used for measuring the skin thickness. Skin thickness was measured at two opposite points with the help of Verniercaliper in mm and averaged for five fruits. Intensity of small ribs in number was measured by counting the number of ribs in one $\mathrm{cm}^{2}$ area and average of five fruits was taken for study. The fruits were cut longitudinally and the number of seeds per fruit was counted. Toughness of the fruit was tested by penetrometer/pressure tester (Ogawa Seiki Co. Ltd. Tokyo, Japan) and was expressed in terms of $\mathrm{kg}$ per $\mathrm{cm}^{2}$. Pressure tester was placed on surface of the fruit and was pressed till the fruit surface ruptured and at this point pressure was noted and as such observation on five randomly selected fruits was averaged for recording the toughness/firmness. The percent fruit damage and number of larvae were correlated with different morphological factors to know the role of different 
morphological traits in imparting resistant or susceptibility in bitter gourd fruits. The data on percentage fruit infestation and larval density per fruit and biochemical fruit traits were analyzed through one-way ANOVA using SPSS software (O’Connor, 2000).

\section{Results and Discussion}

\subsection{Fruit Infestataion}

In crop plants, three principle mechanism viz., non-preference (antixenosis), antibiosis and tolerance are responsible for imparting resistance to insects (Painter, 1968). Non preference denotes a group of plants character and insect response that keep away the insect from using a particular plant or variety for oviposition, food, shelter, or combination of both. Keeping in this view, seventy four promising genotypes of bitter gourd were screened against fruit fly infestation to identify the antixenosis traits involved in host plant selection by the melon fruit fly. On the basis of percent fruit infestation and the average number of larvae per damage fruit, the genotypes were categorized in to different groups i.e. (Highly resistant, resistant, moderately resistant, susceptible, and highly susceptible). There were significant differences in percent fruit infestation and larval density per fruit among the genotypes tested across the years. The fruit infestation during the 2009 and 2010 summer season (Average of two years) ranged from $13.23 \%$ to $83.75 \%$ while larval density per fruit ranged from 2.59 to 8.13 larvae per fruit.

Table 1. Grouping of bitter gourd germplasms/lines/genotypes in to different categories on the basis of percent fruit infestation in summer season (average of two years)

\begin{tabular}{|c|c|c|c|c|c|}
\hline Sr. No. & $\begin{array}{l}\text { Percent fruit } \\
\text { infestation }\end{array}$ & $\begin{array}{l}\text { No. of } \\
\text { larvae/fruit }\end{array}$ & Reaction & $\begin{array}{l}\text { No. of } \\
\text { genotypes }\end{array}$ & Genotypes \\
\hline 1 & $1-10$ & 4.3 & Highly resistant & 0 & - \\
\hline 2 & $11-20$ & 4.9 & Resistant & 5 & IC-248282, Kerala collection-1, VRBT-4, DRAR-1, IC-68314 \\
\hline 3 & $21-50$ & 5.0 & Moderately resistant & 61 & 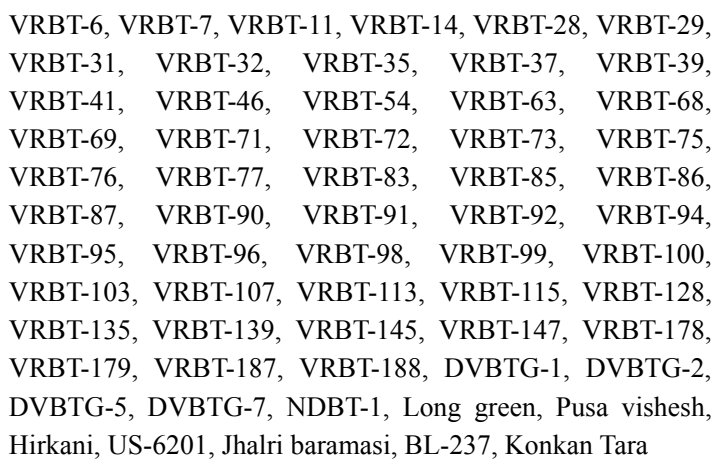 \\
\hline 4 & $51-75$ & 6.1 & Susceptible & 5 & VRBT-21, VRBT-22, VRBT-38, VRBT-93, VRBT-175 \\
\hline 5 & $76-100$ & 8.1 & Highly Susceptible & 3 & Jaunpuri, Arka harit, Pusa Do Mausmi \\
\hline
\end{tabular}

The lowest fruit infestation was observed in the genotypes IC 248282, Kerala collection-1, VRBT-4, DRAR-1 and IC 68314 these were grouped as resistant genotypes while 61 genotypes as moderately resistant, 5 genotypes as susceptible and 3 genotypes highly susceptible. Painter (1951) emphasized the need to identify sources of resistance to target pests, followed by identification of physico-chemical factors involved in host plant selection by the insects, both for oviposition and feeding (Maxwell \& Jennings, 1980). The variety Pusa Do Mausami was most susceptible (having $81.57 \%$ fruit infestation) to the attack of this pest followed by Arka harit (78.17\%) and Jaunpuri (76.21\%). None of the genotypes were found highly resistance, out of 74 genotypes.

\subsection{Morphological Traits}

The difference in the length of bitter gourd fruits of various genotypes were observed significant. However maximum fruit length was observed in the genotype VRBT-11 $(19.4 \mathrm{~cm})$ followed by VRBT-6 $(18.2 \mathrm{~cm})$ while minimum fruit length was observed in the genotype VRBT-94 $(6.18 \mathrm{~cm})$ and VRBT-73 $(6.22 \mathrm{~cm})$. The effect of fruit length was positive on fruit infestation and larval density of fruit fly but the correlation coefficient was not found significant. The fruit diameter was recorded maximum in case of genotype VRBT-187 $(4.28 \mathrm{~cm})$ while the minimum fruit diameter was recorded in genotype VRBT-4 $(2.2 \mathrm{~cm})$ followed by IC $248282(2.56 \mathrm{~cm})$. The fruit diameter showed significant positive effect on fruit infestation and larval density of fruit fly. The fruit flesh thickness was recorded maximum in the genotype VRBT-187 $(3.72 \mathrm{~cm})$ and minimum flesh thickness was 
recorded in the genotype VRBT-4 $(1.86 \mathrm{~cm})$. Fruit skin thickness was maximum in case of the genotype PDM $(0.62 \mathrm{~mm})$ and minimum in the genotypes IC 248282 followed by IC $68314(0.26 \mathrm{~mm})$. The fruit diameter, fruit flesh thickness and skin thickness of resistant genotype was lesser as compared to susceptible and highly susceptible genotypes. Shape of the fruit influences the orientation of fruit flies to a potential ovipositional site (Boller \& Prokopy, 1976). Pal et al. (1984) also found thick and tough rind fruits of IHR 89 and IHR 213 genotypes resistant to melon fruit fly. The fruit infestation is reported to increase with an increase in fruit length and diameter (Jaiswal et al., 1990; Tewatia et al., 1997).

The number of ridge per $\mathrm{cm}^{-2}$ area was maximum in the genotype Harikani $\left(31.2 \mathrm{~cm}^{-2}\right)$ followed by IC 248282 $\left(31.0 \mathrm{~cm}^{-2}\right)$ while it was minimum in the genotype VRBT-37 $\left(7.6 \mathrm{~cm}^{-2}\right)$. The number of ridge per $\mathrm{cm}^{-2}$ area had negative effect on fruit infestation and larval density of fruit fly but the correlation coefficient was found non-significant. The ridge area of resistant genotypes was higher as compared to susceptible genotypes. The highest depth of fruit rib was recorded in the genotypes Jaunpuri $(0.82 \mathrm{~mm})$ and lowest was recorded $(0.33 \mathrm{~mm})$ in the genotypes IC 248282 and DRAR 1. The depth of ribs in resistant genotypes was higher as compared to susceptible genotypes. The number of seed was recorded maximum in the genotype VRBT-96 (31.8) while the number of seed was recorded minimum in the genotype IC 68314 (14.8) followed by IC 248282 (15.0). The number of seeds had positive effect on fruit infestation and larvae density of fruit fly. The fruit toughness varied significantly from each other. The highest fruit toughness was recorded in the genotype IC $248282\left(9.42 \mathrm{~kg} / \mathrm{cm}^{2}\right)$ followed by Kerala collection- $1\left(8.81 \mathrm{~kg} / \mathrm{cm}^{2}\right)$. While minimum fruit toughness was recorded in case of genotype VRBT-93 $\left(7.19 \mathrm{~kg} / \mathrm{cm}^{2}\right)$ followed by VRBT-38 $\left(7.2 \mathrm{~kg} / \mathrm{cm}^{2}\right)$. The fruit toughness had significant negative effect on fruit infestation and larval density of fruit fly. Fruit toughness of resistant genotypes was higher as compared to susceptible and highly susceptible genotypes. Similar result is reported by Chelliah and Sambandam (1971) they have reported that egg laying by the melon fruit fly is only 11.77 percent of the fruits having tough rind in $C$. callosus, while egg laying by the fruit fly was recorded as high as 87.33 percent fruits in the susceptible variety Delta gold. Similarly, resistance to squash vine borer in Cucurbita spp. has also been reported dew to tough vascular bundles (Howe, 1949). Pal et al. (1984) also found thick and tough rind fruits of IHR 89 and IHR 213 genotypes resistant to melon fruit fly.

Table 2. Morphological characters of the fruits of bitter gourd genotypes screened against fruit fly infestation during summer sseason of the year 2009 and 20010 (Average of two years)

\begin{tabular}{|c|c|c|c|c|c|c|c|c|c|c|}
\hline Genotypes & $\begin{array}{l}\text { Fruit } \\
\text { damage } \\
(\%)\end{array}$ & $\begin{array}{l}\text { No. of } \\
\text { larvae/ } \\
\text { fruit }\end{array}$ & $\begin{array}{l}\text { Fruit } \\
\text { length } \\
(\mathrm{cm})\end{array}$ & $\begin{array}{l}\text { Fruit } \\
\text { diameter } \\
(\mathrm{cm})\end{array}$ & $\begin{array}{l}\text { Fruit flesh } \\
\text { thickness } \\
(\mathrm{cm})\end{array}$ & $\begin{array}{l}\text { Fruit skin } \\
\text { thickness } \\
(\mathrm{mm})\end{array}$ & $\begin{array}{l}\text { Ridge } \\
\text { area } \\
\left(\mathrm{cm}^{2}\right)\end{array}$ & $\begin{array}{l}\text { Rib } \\
\text { depth } \\
(\mathrm{mm})\end{array}$ & $\begin{array}{l}\text { No. of } \\
\text { seeds }\end{array}$ & $\begin{array}{l}\text { Fruit } \\
\text { toughness } \\
\left(\mathrm{kg} / \mathrm{cm}^{2}\right)\end{array}$ \\
\hline VRBT-4 & 18.76 & 3.36 & 8.34 & 2.24 & 1.90 & 0.34 & 17.4 & 0.5 & 18.4 & 8.47 \\
\hline VRBT-6 & 31.89 & 4.35 & 17.44 & 3.53 & 3.01 & 0.52 & 15.6 & 0.52 & 29.5 & 7.32 \\
\hline VRBT-7 & 22.78 & 3.42 & 13.88 & 3.29 & 2.92 & 0.37 & 15.6 & 0.49 & 25.9 & 8.425 \\
\hline VRBT-11 & 29.01 & 4.10 & 19.01 & 3.54 & 3.03 & 0.51 & 12.6 & 0.56 & 31.5 & 7.5 \\
\hline VRBT-14 & 31.34 & 4.69 & 7.63 & 2.65 & 2.16 & 0.49 & 10.2 & 0.51 & 18.0 & 7.7 \\
\hline VRBT-21 & 67.01 & 6.74 & 8.26 & 3.65 & 3.19 & 0.46 & 18.7 & 0.52 & 18.8 & 7.305 \\
\hline VRBT-22 & 56.29 & 6.14 & 10.38 & 3.17 & 2.62 & 0.55 & 15.1 & 0.59 & 20.4 & 7.415 \\
\hline VRBT-28 & 31.15 & 4.68 & 14.12 & 3.29 & 2.78 & 0.51 & 13.1 & 0.57 & 22.8 & 7.495 \\
\hline VRBT-29 & 36.71 & 4.91 & 16.88 & 4.17 & 3.62 & 0.55 & 12.9 & 0.54 & 28.8 & 7.485 \\
\hline VRBT-31 & 26.85 & 4.25 & 8.33 & 3.6 & 3.11 & 0.49 & 19.1 & 0.53 & 18.5 & 8.28 \\
\hline VRBT-32 & 31.19 & 4.63 & 12.79 & 3.59 & 3.06 & 0.53 & 11.9 & 0.56 & 24.1 & 7.585 \\
\hline VRBT-35 & 46.49 & 5.65 & 7.25 & 4.1 & 3.54 & 0.56 & 10.3 & 0.53 & 19.1 & 7.36 \\
\hline VRBT-37 & 36.12 & 5.08 & 10.61 & 3.52 & 3.03 & 0.49 & 7.2 & 0.50 & 21.3 & 7.465 \\
\hline VRBT-38 & 57.33 & 6.07 & 16.95 & 4.09 & 3.59 & 0.50 & 10.3 & 0.54 & 30.2 & 7.20 \\
\hline VRBT-39 & 32.43 & 4.71 & 10.83 & 3.67 & 3.23 & 0.44 & 13.8 & 0.51 & 21 & 7.92 \\
\hline VRBT-41 & 26.16 & 4.27 & 10.65 & 3.30 & 2.77 & 0.53 & 13.7 & 0.49 & 18.6 & 8.225 \\
\hline VRBT-46 & 30.31 & 4.53 & 8.05 & 3.56 & 3.09 & 0.47 & 11.8 & 0.55 & 17.4 & 7.84 \\
\hline VRBT-54 & 26.28 & 4.09 & 13.54 & 3.36 & 2.88 & 0.48 & 13.7 & 0.57 & 23.5 & 8.275 \\
\hline VRBT-63 & 31.54 & 4.67 & 10.16 & 2.74 & 2.30 & 0.44 & 10.8 & 0.50 & 18.9 & 8.11 \\
\hline VRBT-68 & 30.26 & 4.48 & 11.00 & 3.68 & 3.19 & 0.49 & 12.1 & 0.53 & 21.3 & 7.735 \\
\hline VRBT-69 & 30.64 & 4.57 & 9.38 & 3.12 & 2.76 & 0.36 & 17.2 & 0.44 & 18.9 & 7.64 \\
\hline VRBT-71 & 25.31 & 3.97 & 7.89 & 3.55 & 3.07 & 0.48 & 14.2 & 0.53 & 18.5 & 8.225 \\
\hline VRBT-72 & 30.24 & 4.57 & 6.44 & 3.20 & 2.74 & 0.46 & 10.0 & 0.51 & 17.2 & 8.175 \\
\hline
\end{tabular}




\begin{tabular}{|c|c|c|c|c|c|c|c|c|c|c|}
\hline VRBT-73 & 28.74 & 4.37 & 6.82 & 2.57 & 2.20 & 0.37 & 17.7 & 0.47 & 15.9 & 8.435 \\
\hline VRBT-75 & 29.74 & 4.56 & 13.06 & 3.47 & 2.94 & 0.53 & 12.3 & 0.57 & 22.7 & 7.545 \\
\hline VRBT-76 & 28.51 & 4.46 & 8.63 & 3.14 & 2.65 & 0.49 & 17.3 & 0.47 & 19.5 & 8.335 \\
\hline VRBT-77 & 26.48 & 4.15 & 7.34 & 3.43 & 3.00 & 0.43 & 13.9 & 0.50 & 18.2 & 8.39 \\
\hline VRBT-83 & 29.37 & 4.44 & 8.91 & 3.07 & 2.54 & 0.53 & 15.9 & 0.55 & 18.6 & 8.415 \\
\hline VRBT-85 & 37.01 & 5.03 & 15.3 & 3.71 & 3.14 & 0.57 & 16.5 & 0.54 & 26.9 & 7.425 \\
\hline VRBT-86 & 29.42 & 4.42 & 10.7 & 3.62 & 3.12 & 0.5 & 10.0 & 0.53 & 21.3 & 7.515 \\
\hline VRBT-87 & 34.67 & 4.83 & 17.24 & 3.45 & 2.92 & 0.53 & 9.40 & 0.58 & 28.7 & 7.39 \\
\hline VRBT-90 & 32.85 & 4.80 & 7.36 & 3.35 & 2.81 & 0.54 & 16.8 & 0.51 & 18.0 & 7.51 \\
\hline VRBT-91 & 26.29 & 3.54 & 16.51 & 3.57 & 3.14 & 0.43 & 19.2 & 0.52 & 30.4 & 8.19 \\
\hline VRBT-92 & 28.61 & 4.32 & 6.30 & 3.24 & 2.76 & 0.48 & 10.6 & 0.53 & 17.7 & 7.82 \\
\hline VRBT-93 & 55.11 & 6.16 & 7.10 & 3.34 & 2.89 & 0.45 & 14.8 & 0.48 & 16.0 & 7.195 \\
\hline VRBT-94 & 28.47 & 4.34 & 5.98 & 2.76 & 2.31 & 0.45 & 16.7 & 0.45 & 16.9 & 8.125 \\
\hline VRBT-95 & 24.53 & 3.96 & 13.72 & 3.56 & 3.01 & 0.55 & 13.0 & 0.46 & 24.0 & 7.45 \\
\hline VRBT-96 & 31.80 & 4.54 & 16.63 & 3.76 & 3.25 & 0.51 & 13.7 & 0.52 & 31.3 & 7.465 \\
\hline VRBT-98 & 27.41 & 4.27 & 8.71 & 3.17 & 2.76 & 0.41 & 16 & 0.43 & 19.3 & 8.135 \\
\hline VRBT-99 & 28.90 & 4.44 & 14.52 & 3.64 & 3.09 & 0.55 & 15.3 & 0.50 & 25.5 & 7.31 \\
\hline VRBT-100 & 34.68 & 4.84 & 8.55 & 3.63 & 3.14 & 0.49 & 12.7 & 0.49 & 17.2 & 7.5 \\
\hline VRBT-103 & 27.63 & 4.31 & 15.96 & 3.43 & 2.98 & 0.45 & 13.4 & 0.45 & 29.0 & 8.18 \\
\hline VRBT-107 & 25.12 & 4.05 & 13.68 & 3.46 & 2.97 & 0.49 & 11.7 & 0.59 & 23.8 & 7.85 \\
\hline VRBT-113 & 29.13 & 4.44 & 10.70 & 3.01 & 2.55 & 0.46 & 14.0 & 0.50 & 18.4 & 8.11 \\
\hline VRBT-115 & 34.93 & 4.92 & 17.67 & 3.27 & 2.76 & 0.51 & 12.7 & 0.53 & 29.2 & 7.325 \\
\hline VRBT-128 & 28.86 & 4.34 & 14.40 & 3.40 & 2.91 & 0.49 & 14.3 & 0.57 & 24.2 & 7.605 \\
\hline VRBT-135 & 34.33 & 4.79 & 10.12 & 3.40 & 2.87 & 0.53 & 14.5 & 0.56 & 19.7 & 7.305 \\
\hline VRBT-139 & 29.96 & 4.58 & 10.21 & 3.67 & 3.15 & 0.52 & 14.4 & 0.52 & 21.5 & 7.78 \\
\hline VRBT-145 & 31.57 & 4.71 & 9.53 & 3.47 & 2.95 & 0.52 & 14.2 & 0.54 & 17.5 & 7.645 \\
\hline VRBT-147 & 37.27 & 5.10 & 17.32 & 4.15 & 3.58 & 0.57 & 11.5 & 0.57 & 30.7 & 7.305 \\
\hline VRBT-175 & 65.54 & 6.68 & 9.90 & 3.22 & 2.73 & 0.49 & 11.6 & 0.55 & 20.4 & 7.31 \\
\hline VRBT-178 & 28.91 & 4.37 & 7.95 & 3.69 & 3.14 & 0.55 & 14.3 & 0.46 & 19.7 & 7.62 \\
\hline VRBT-179 & 27.92 & 4.29 & 10.80 & 3.42 & 2.95 & 0.47 & 12.0 & 0.57 & 20.7 & 8.3 \\
\hline VRBT-187 & 30.67 & 4.65 & 13.16 & 4.36 & 3.81 & 0.55 & 11.5 & 0.60 & 26.2 & 7.385 \\
\hline VRBT-188 & 34.16 & 4.73 & 16.34 & 4.0 & 3.44 & 0.56 & 8.3 & 0.70 & 31.4 & 7.3 \\
\hline DVBTG-1 & 44.16 & 5.60 & 15.52 & 2.94 & 2.53 & 0.41 & 12.0 & 0.44 & 26.0 & 7.895 \\
\hline DVBTG-2 & 33.74 & 4.61 & 11.03 & 3.11 & 2.62 & 0.49 & 11.4 & 0.55 & 20.4 & 8.105 \\
\hline DVBTG-5 & 27.62 & 4.23 & 12.81 & 3.05 & 2.61 & 0.44 & 12.0 & 0.47 & 23.5 & 8.19 \\
\hline DVBTG-7 & 27.43 & 4.28 & 13.57 & 3.39 & 2.97 & 0.42 & 12.2 & 0.44 & 23.2 & 8.195 \\
\hline DRAR-1 & 18.12 & 3.18 & 10.96 & 2.79 & 2.51 & 0.28 & 19.3 & 0.35 & 17.4 & 8.455 \\
\hline NDBT-1 & 40.11 & 5.20 & 8.27 & 3.24 & 2.81 & 0.43 & 14.8 & 0.60 & 16.8 & 7.875 \\
\hline Long green & 26.42 & 4.17 & 7.63 & 3.41 & 3.15 & 0.26 & 23.1 & 0.54 & 17.1 & 8.475 \\
\hline Jaunpuri & 76.21 & 7.42 & 14.48 & 3.97 & 3.67 & 0.30 & 18.3 & 0.80 & 26.5 & 7.35 \\
\hline Arkaharit & 78.17 & 7.73 & 9.79 & 3.67 & 3.17 & 0.50 & 19.9 & 0.60 & 18.6 & 7.6 \\
\hline PusaVishesh & 39.48 & 5.19 & 10.97 & 3.61 & 3.12 & 0.49 & 28.8 & 0.58 & 21.3 & 8.34 \\
\hline IC-68314 & 18.11 & 3.20 & 7.40 & 2.71 & 2.45 & 0.26 & 25.3 & 0.50 & 14.8 & 8.475 \\
\hline IC-248282 & 13.64 & 2.74 & 6.29 & 2.60 & 2.32 & 0.28 & 31.1 & 0.38 & 13.1 & 9.4 \\
\hline Hirkani & 30.91 & 4.63 & 10.83 & 3.81 & 3.48 & 0.33 & 32.1 & 0.67 & 24.5 & 8.565 \\
\hline PDM & 81.57 & 7.84 & 9.58 & 3.53 & 2.92 & 0.61 & 18.2 & 0.64 & 21 & 7.525 \\
\hline US-6201 & 33.87 & 4.77 & 7.32 & 3.18 & 2.69 & 0.49 & 10.8 & 0.55 & 17.9 & 8.4 \\
\hline Jhalribaramasi & 26.11 & 3.91 & 13.2 & 3.74 & 3.45 & 0.29 & 18.7 & 0.64 & 26.6 & 7.555 \\
\hline BL-237 & 26.25 & 4.12 & 8.33 & 3.64 & 3.34 & 0.3 & 27.8 & 0.52 & 17.2 & 7.625 \\
\hline Konkan Tara & 24.80 & 4.09 & 7.42 & 3.54 & 3.25 & 0.29 & 29.8 & 0.56 & 19.00 & 7.475 \\
\hline $\begin{array}{l}\text { Kerala } \\
\text { collection-1 }\end{array}$ & 15.68 & 2.84 & 10.9 & 3.21 & 2.83 & 0.38 & 23.2 & 0.53 & 26.10 & 8.8 \\
\hline \multicolumn{3}{|c|}{ C.D. $(\mathrm{P}=0.05 \%)$} & 1.06 & 0.31 & 0.30 & 0.09 & 2.42 & 0.09 & 3.49 & 0.04 \\
\hline \multicolumn{3}{|c|}{$\mathrm{SEM} \pm$} & 0.54 & 0.155 & 0.15 & 0.04 & 1.23 & 0.045 & 1.77 & 0.015 \\
\hline
\end{tabular}




\subsection{Fruit Damage and Larval Density}

The larval density increased with the increase in percent fruit infestation and showed significant positive correlation $(\mathrm{r}=0.98)$. Dhillon et al. (2005) was also reported that the genotypes with low fruit fly infestation had low larval numbers in the fruits and there was positive correlation $(\mathrm{r}=0.96)$ between percentage fruit infestation and number of larvae per fruit. The average of two years data on fruit infestation (\%) and larval density (fruit ${ }^{-1}$ ) showed significant positive correlation with fruit diameter $(r=0.32$ and 0.35$)$, flesh thickness $(r=0.27$ and $0.28)$, skin thickness $(r=0.29$ and 0.37$)$ and depth of ribs $(r=0.46$ and 0.46$)$ and negative correlation with fruit toughness $(r=-0.52$ and -0.57$)$. The toughness of fruits appeared to play significant role in fruit fly infestation. The length of fruits and number of seeds had no significant impact on fruit fly infestation though they had positive correlation with fruit fly infestation $(\mathrm{r}=0.05$ and $0.04,0.07$ and 0.05$)$ respectively. The number of ridge showed non-significant negative correlation with fruit fly infestation $(r=-0.11$ and -0.18$)$. There was a strong correlation between number of ribs and fruit toughness, and these traits can be used as markers to select bitter gourd genotype resistant to melon fruit fly. In the present study there was a significant and positive correlation ( $\mathrm{r}$ $=$ ) between percent fruit infestation and larval density (fruit ${ }^{-1}$ ). The fruit infestation (\%) and larval density (fruit ${ }^{1}$ ) were positively correlated with flesh thickness, fruit diameter, fruit length, skin thickness and depth of ribs and negatively correlated with fruit toughness. There was a strong correlation between number of ribs and fruit toughness, and similar results have been reported by Dhillon et al. (2005).

Table 3. The correlation coefficients of the bitter gourd fruit damage, larval density and morphological characters of the fruits of different germplasms/lines/genotypes of bitter gourd during summer season of the year 2009 and 2010

\begin{tabular}{|c|c|c|c|c|c|c|c|c|c|c|}
\hline Morphological Traits & $\begin{array}{l}\text { Fruit } \\
\text { damage } \\
(\%)\end{array}$ & $\begin{array}{l}\text { Larval } \\
\text { density } \\
\text { (fruit }^{-1} \text { ) }\end{array}$ & $\begin{array}{l}\text { Fruit } \\
\text { length } \\
(\mathrm{cm})\end{array}$ & $\begin{array}{l}\text { Fruit } \\
\text { diameter } \\
(\mathrm{cm})\end{array}$ & $\begin{array}{l}\text { Fruit flesh } \\
\text { thickness } \\
(\mathrm{cm})\end{array}$ & $\begin{array}{l}\text { Fruit skin } \\
\text { thickness } \\
(\mathrm{mm})\end{array}$ & $\begin{array}{l}\text { No of ridge } \\
\left(\mathrm{cm}^{-2}\right) \text { area } \\
\text { of fruit }\end{array}$ & $\begin{array}{l}\text { Ridge } \\
\text { depth } \\
(\mathrm{mm})\end{array}$ & $\begin{array}{l}\text { No of } \\
\text { Seeds } \\
\text { fruit }^{-1} \text { ) }\end{array}$ & $\begin{array}{l}\text { Fruit } \\
\text { toughness } \\
\left(\mathrm{kg} / \mathrm{cm}^{2}\right) \\
\text { of fruits }\end{array}$ \\
\hline Fruit damage (\%) & 1.00 & & & & & & & & & \\
\hline Larval density (fruit ${ }^{-1}$ ) & $0.98 * *$ & 1.00 & & & & & & & & \\
\hline Fruit length $(\mathrm{cm})$ & 0.05 & 0.04 & 1.00 & & & & & & & \\
\hline Fruit diameter $(\mathrm{cm})$ & $0.32 * *$ & $0.35^{* *}$ & $0.42 * *$ & 1.00 & & & & & & \\
\hline Fruit flesh thickness $(\mathrm{cm})$ & $0.27^{*}$ & $0.28^{*}$ & $0.39 * *$ & $0.98 * *$ & 1.00 & & & & & \\
\hline Fruit skin thickness (mm) & $0.29 *$ & $0.37 * *$ & $0.29 *$ & $0.40^{* *}$ & 0.20 & 1.00 & & & & \\
\hline No of ridge $\left(\mathrm{cm}^{-2}\right)$ area of fruit & -0.11 & -0.18 & $-0.29 *$ & -0.14 & 0.00 & $-0.62 * *$ & 1.00 & & & \\
\hline Ridge depth (mm) & $0.46^{* *}$ & $0.46^{* *}$ & $0.25^{*}$ & $0.51 * *$ & $0.51^{* *}$ & 0.17 & 0.00 & 1.00 & & \\
\hline No. of seed $\left(\right.$ fruit $\left.^{-1}\right)$ & 0.07 & 0.05 & $0.94 * *$ & $0.53 * *$ & $0.50^{* *}$ & $0.30 * *$ & $-0.26^{*}$ & $0.34 * *$ & 1.00 & \\
\hline Fruit toughness $\left(\mathrm{kg} / \mathrm{cm}^{2}\right)$ of fruits & $-0.52 * *$ & $-0.57 * *$ & $-0.38 * *$ & $-0.57 * *$ & $-0.49 * *$ & $-0.53 * *$ & $0.43 * *$ & $-0.36^{* *}$ & $-0.39 * *$ & 1.00 \\
\hline
\end{tabular}

\section{Conclusion}

Development of muskmelon varieties/genotypes resistant to fruit fly has been restricted in India due to inadequate information on the sources of plant traits associated with resistance to pest infestations. Our study was proved that the various morphological traits of bitter gourd of varieties/genotypes fruit traits allied with resistance against melon fruit fly in terms of fruit infestation and larval density under field conditions. The resistance varieties can play a vital role integrated pest management in bitter gourd.

\section{References}

Agarwal, M. L., Sharma, D. O., \& Rahman, O. (1987). Melon fruit fly and its control. Hort, 32(2), 10-11.

Anonymous. (1992). Report on infrastructure for export of agricultural commodities and processed food (p. 44). Govt. of India, Planning commission (Agriculture Division), Yojana Bhawan, New Delhi.

Aslam, M., \& Stockley, I. H. (1979). Interaction between curry ingredient (Karela) and drug (chlorpropamide). Lancet, 1(8116), 607. https://doi.org/10.1016/S0140-6736(79)91028-6

Awasthi, C. P., \& Jaiswal, R. C. (1986). Biochemical composition and nutritional quality of fruits of bitter gourd grown in Uttar Pradesh. Prog. Hort., 18, 265-269. 
Baldwa, V. S., Bhandari, C. M., Pangaria, A., \& Goyal, R. K. (1977). Clinical trial in patients with diabetes mellitus of an insulin like compounds obtained from plant source. Uppasal J. Med. Sci., 82, 39. https://doi.org/10.3109/03009737709179057

Boller, E. F., \& Prokopy, R. J. (1976). Bionomics and management of Rhagoletis. Annu. Rev. Ent., 21, 223-246. https://doi.org/10.1146/annurev.en.21.010176.001255

Chelliah, S., \& Sambandam, C. N. (1971). Role of certain mechanical factors in Cucumis callosus (Rottl.) Cogn. in imparting resistance to Dacus cucurbitae. AUARA, 3, 48-53.

De-Ponti, O. M. B. (1977). Resistance in Cucumis sativus L. to Tetranychus urticae Koch. I. The role of plant breeding in integrated control. Euphytica, 26, 633. https://doi.org/10.1007/BF00021688

Dhillon, M. K., Singh, R., Naresh, J. S., \& Sharma, N. K. (2005). Influence of physio-chemical traits of bitter gourd, Momordica charantia L. on larval density and resistance to melon fruit fly, Bactrocera cucurbitae (coquillent). J. Applied Entomology, 129(7), 395-399. https://doi.org/10.1111/j.1439-0418.2005.00911.x

Fletcher, B. S. (1987). The biology of Dacine fruit flies. Annu. Rev. Entomol., 32, 115-144. https://doi.org/ 10.1146/annurev.en.32.010187.000555

Grover, J. K., \& Yadav, S. P. (2004). Pharmacological action and potential uses of Momordica charentia L. J. Ethnopharmacol, 93(1), 123-132. https://doi.org/10.1016/j.jep.2004.03.035

Gupta, J. N., \& Verma, A. N. (1979). Relative efficacy of insecticides as contact poison to the adults of melon fruit fly, Dacus cucurbitae (Coq). Indian J. Ent., 41, 117-120.

Howe, W. L. (1949). Factors affecting the resistance of certain cucurbits to squash borer. J. Econ. Ent., 42, 321. https://doi.org/10.1093/jee/42.2.321

Jaiswal, R. C., Kumar, S., Raghav, M., \& Singh D. K. (1990). Variation in quality traits of bitter gourd (Momordica charantia L.) cultivars. Veg. Sci., 17, 186-190.

Kapoor, V. C. (1993). Indian fruit flies (p. 228). Oxford and IBH Publication, India.

Kedar, P., \& Chakraborti, C. H. (1982). Effect of bitter gourd and glibenclamide in streptozotocin induced diabetes Mellitus. Indian J. Exp. Biol., 28, 232-235.

Kushwaha, K. S., Pareek, B. L., \& Noor, A. (1973). Fruit fly damage in cucurbits at Udaipur. Univ. Udaipur Res. $J ., 11,22-23$.

Lall, B. S. (1964). Vegetable pests. Entomology in India (pp. 199-202). Ent. Soc., India, New Delhi.

Lall, B. S., \& Singh, B. N. (1969). Studies on the biology and control of melon fly, D. cucurbitae (Dip.: Teph.). Labdev J. Sci. and Tech., 7B(2), 148-153.

Lall, B. S., \& Sinha, S. N. (1959). Biology of melon fruit fly, Dacus cucurbitae Coquillet. Sci. \& Cult., 25, 25.

Lee, W. Y. (1988). The control programme of oriental fruit fly in Taiwan. Spec. Publ. No. 2, Entomol. Soc., Rep. China (pp. 51-60).

Lefroy, H. M. (1909). Indian Insect Life (pp. 303-362). Thacker, Spink and Co., Calcutta.

Lotlikar, M. M., \& Rajaramrao, M. R. (1966). Pharmacology of a hypoglycaemic principal isolated from the fruits of Momordica charentia L. Indian. J. Pharm., 28, 129.

Mauricio, R. (1998). Costs of resistance to natural enemies in field populations of the annual plant Arabidopsis thaliana. American Naturalist, 151, 20-28. https://doi.org/10.1086/286099

Mauricio, R., \& Rausher, M. D. (1997). Experimental manipulation of putative selective agents provides evidence for the role of natural enemies in the evolution of plant defense. Evolution, 51, 1435-1444. https://doi.org/10.2307/2411196

Maxwell, P. G., \& Jennings, P. R. (1980). Breeding plants resistance to insects (p. 124). A Wiley Interscience Publication, New York.

Mishra, V. K., \& Bhatnagar, K. N. (1978). Studies on population and control of some pests of cucurbits, Univ. Udaipur Res. J., 16, 143-144.

Morton, J. F. (1967). The balsam pear-An edible, medicinal and toxic plant. Econ. Bot., 21, 57-68. https://doi.org/10.1007/BF02897176

Munro, K. H. (1984). A taxonomic treatise on the Decidae (Tephritoidea: Diptera) of Africa. Memories of the 
Department of Agriculture, Republic of South Africa, 61, 1-313.

Narayan, E. S. (1953). Fruit fly pest of orchards and Kitchen garden. Indian Farming, 3(4), 29-31.

Narayan, E. S., \& Batra, H. N. (1960). Fruit flies and their control (pp. 28-29). 'Monograph' I.C.A.R., New Delhi.

Nath, P. (1966). Varietal resistance of gourds to the fruit flies. Indian J. Hort., 23(2), 69-79.

Nath, P. (2008). Increased trend in production and consumption. Survey of Indian Agriculture (p. 66).

O'Connor, B. P. (2000). SPSS and SAS programs for determining the number of components using parallel analysis and Velicer's MAP test. Behavior Research Methods, Instruments \& Computers, 32, 396-402. https://doi.org/10.3758/BF03200807

Painter, R. H. (1951). Insects resistance in crop plants (p. 520). The Macmillan Co., New York. https://doi.org/ 10.1097/00010694-195112000-00015

Painter, R. H. (1968). Insects resistance in crop plants (p. 520). The University Press of Kansas, Lawrence and London.

Pal, A. B., Srinivasan, K., \& Douode, S. D. (1984). Sources of resistance to melon fruit fly in bitter gourd and possible mechanism of resistance. SABARAO J., 16, 57-69.

Panday, A. K., Nath, P., \& Rai, A. B. (2008). Efficacy of some ecofriendly insecticides, poisons baits and their combinations against bitter gourd infestation by melon fruit fly (Bactrocera cucurbitae Coquillet). Veg. Sci., 35(2), 152-155.

Panday, A. K., Nath, P., Rai, A. B., \& Kumar, A. (2009). Screening of some bitter gourd varieties/germplasms on the basis of some biological and biometrical parameters of melon fruit fly (Bactrocera cucurbitae Coquillet). Veg. Sci., 36(Suppl. 3), 399-400.

Pareek, B. L., \& Kavadia, V. S. (1986). Seasonal incidence of insect pests of cucurbits in Rajasthan. Ann. Arid Zone, 25(4), 300-311.

Singh, S., \& Singh, S. (1961). Field key for the determination of insects infesting vegetables. Punjab Horti. J., $1(1), 57-59$.

Stamp, N. (2003). Out of the quagmire of plant defense hypotheses. Quarterly Review of Biology, 78, 23-55. https://doi.org/10.1086/367580

Tewatia, A. S. (1997). Melon fruit fly resistance in cucurbits-A Review. Veg. Sci., 24(2), 79-82.

\section{Copyrights}

Copyright for this article is retained by the author(s), with first publication rights granted to the journal.

This is an open-access article distributed under the terms and conditions of the Creative Commons Attribution license (http://creativecommons.org/licenses/by/4.0/). 